\title{
Vi vet mer enn vi kan begripe
}

Da jeg for noen år siden sto på toppen av Empire State Building, dukket det opp en assosiasjon som siden er blitt sittende fast. Gatene, med hundrevis av gule taxier som pilte frem og tilbake langt der nede, minnet om et nettverkskart over intracellulære signalveier. Tre hundre meters høyde gir en fantastisk utsikt, men knapt noen innsikt - i byen, i menneskene eller i hvorfor taxiene beveger seg som de gjør. Et videokamera koblet til en datamaskin kunne registrert bilenes bevegelser med nøyaktige koordinater i en time, et døgn, et år. De innsamlede data kunne gitt et intrikat kart over hvordan trafikken beveger seg, men like fullt etterlatt meg i detaljmettet uvitenhet om hvorfor bilene kjører slik - omtrent like uvitende som man føler seg når foreleseren trekker frem et gjennomarbeidet pilkart over intracellulære signalveier. Jeg rekker aldri å stille spørsmål til slike kart, forsøker bare febrilsk å få med meg foreleserens forklaring. Dessverre er forklaringen oftere en beskrivelse enn en kilde til forståelse. Antakelig kan vi ikke laste foreleseren for det. Hvordan kan hun vite hvilken betydning hvert enkelt molekyl har? Vi ynder å analysere faktorene én for én i elegante modeller, men virkeligheten er full av forstyrrende variabler. Mangel på et spesielt enzym kan føre til tap av funksjon i en modell, men ikke i naturen, fordi der overtar andre enzymer funksjonen. Og når alle variabler er til stede, blir nettverket av interagerende faktorer så stort at selv en todimensjonal virkelighet i PowerPoint blir for komplisert å begripe.

For dem av oss som har tatt vare på studietidens lærebøker, kan det være spennende å se hvilke kapitler som inneholdt kimen til ny viten og som har vokst seg større i nye utgaver. Det kan også være interessant å legge merke til at enkelte kapitler er blitt borte. I immunologiboken min fra tidlig i 1990-årene er det flotte kapitler om CD8-positive suppressor-T-celler. Kort tid senere forsvant suppressorcellene fra lærebøkene, og man kunne pakke bort stabler av artikler i tunge tidsskrifter som indikerte at CD8-positive T-celler effektivt undertrykte immunresponser. Problemet var at cellene stort sett bare fungerte slik i laboratoriet, mens de viste seg å ha helt andre funksjoner i kroppen. Om siste ord er sagt i denne diskusjonen, vites ikke. Uansett illustrerer historien hvor vanskelig det er å overføre kunnskap fra forenklede modellsystemer til den komplekse naturen. Og at ydmykhet er en dyd, men ikke alltid forskerens fremste egenskap.

I genene ligger naturens hemmelige oppskrift på hvordan vi blir til og hvem vi skal bli. Da man rundt 1990 startet kartleggingen av det humane genom, var forventningene enorme. Ti år senere, i 2000, var det humane genom sekvensert. Men hvor mye mer forstår vi av mennesket etter at alle våre gener er beskrevet? Trolig langt mindre enn vi hadde håpet. Det har vist seg å være enklere å beskrive genetiske varianter enn å avgjøre hva slags betydning de har. En hovedforklaring er at hvert enkelt gen ikke fungerer på egen hånd, det er innvevd i et mikrokosmos av interfererende gener, proteiner og RNA-molekyler. Antakelig sto det skrevet i Mozarts gener at han ville bli musikalsk, men vi kan fortsatt ikke tolke skriften. Hvorfor tåler noen å røyke til de blir 90 år? Genetisk disposisjon dreier seg i vår tid sjelden om sterke årsakssammenhenger, men om svake assosiasjoner som bare kan påvises ved komplisert statistikk. Kartleggingen av genomet var ikke mållinjen, snarere startskuddet. Mange molekylærgenetikere vil nok kjenne seg igjen i den gamle betraktning at kunnskap kan sammenliknes med en kule, læring med å stige opp fra kulens overflate. Jo høyere opp fra kulen man kommer, desto mer viser det seg at man ikke vet. Kanskje vil naturvitenskapens suksess frembringe så store mengder data at det oppstår behov for helt andre arbeidsverktøy? Samfunnsvitenskapelige spørsmål kan sjelden besvares med testbare hypoteser. Dette skyldes ikke mangel på data, snarere mengden og kompleksiteten av all informasjon som er tilgjengelig. Forskjellene mellom naturvitenskap og samfunnsvitenskap er store, utviklingen kan likevel bringe fagene nærmere hverandre. Hvis cellebiologien blir like kompleks som samfunnet, hvilken metodikk skal vi da bruke?

Jo Tenfjord har fremhevet at vi er forskjellige utenpå. Faktum er at vi ikke er spesielt like innvendig heller. Enkelte får paradoksal uro av benzodiazepiner, noen har nytte av blodtrykksmedisin A og andre av blodtrykksmedisin B. Hva så med skreddersydd medisin, tilpasset alder, genetiske polymorfismer og andre individuelle særtrekk? Det må være vår ambisjon at vi bedre skal kunne forutsi hva som virker på hvem. Samtidig gjør vi klokt i å innse at veien til skreddersydd medisin vil være lang og full av kryssende trafikk. Individuell variasjon i medikamentrespons kan sjelden forklares ved én enkelt faktor, f.eks. en reseptorpolymorfisme. Når vi baserer oss på empiriske studier fra store pasientgrupper, er det ikke enkelt å praktisere individtilpasset og samtidig evidensbasert medisin.

Det kan være besnærende å tenke at fremtidens forskere vil kjenne biologien så godt at de kan designe et nytt medikament i laboratoriet, prøve det ut i dyremodeller og forutsi hvordan det vil virke i hver enkelt pasient. Men fremtidens leger må nok også prøve og feile med virkelige, snarere enn virtuelle, pasienter. Antakelig vil det være like enkelt å predikere en medikamenteffekt ut fra modellsystemer som det var å forutsi finanskrisen. Få tror at mangel på informasjon var Allan Greenspans problem da han mente det ville være gunstig å deregulere lånemarkedet og senke renten ned mot null. Vi kan også sammenlikne med å beregne hvordan New York ville sett ut $\mathrm{i}$ dag om noen hadde bygd en fabrikk på tomten til Times Square i 1848. Det blir for mange baller i luften - og for mange taxier i gatene.

\section{Jon Amund Kyte}

jon.amund.kyte@rr-research.no

Jon Amund Kyte (f.1972) er lege ved Oslo universitetssykehus, Radiumhospitalet, og medisinsk redaktør i Tidsskriftet. Han har doktorgrad innen immungenterapi mot kreft. 